\title{
iorhs
}

\author{
$3^{\text {rd }}$ International Conference On Research In \\ HUMANITIES \& SOCIAL SCIENCES
}

11-13 September 2020

Brussels, Belgium

\section{Orthodox Romanian Church during the Popular Democracy Regime}

\author{
Dr. Dorin Gabriel Pandele \\ Low Danube University of Galați, Romania
}

\begin{abstract}
.
The period of popular democracy in Romania meant a huge challenge for the Romanian Orthodox Church, immediately after the gradual establishment of communism, as its own existence within the framework of the new order was questioned. The challenges that the Church had to defy under the popular democratic regime were: the persecution of the clergy by the State Security, the loss of Church assets, the election of new bishops, the closing of monasteries, the reform of theological education, the training of clergy in communist political projects, collectivization of agriculture, catechesis of young people, youth movement, etc. Under such conditions, the Church, through Patriarch Justinian (1948-1977) initiated an action of passive resistance to the repressive measures of the regime, making under certain conditions some compromises to keep intact the essence of the evangelical message, through an acceptable discourse by both parties and, on the other hand, the Church cultivated an active resistance that was put into operation by sacrificing thousands of priests and believers who were persecuted especially for their faith.
\end{abstract}

Keywords: Patriarch Justinian, CNSAS Archives, challenges, double discourse 


\section{$3^{\text {rd }}$ International Conference On Research In HUMANITIES \& SOCIAL SCIENCES}

\section{Introduction}

The democratic-popular regime gradually settled in Romania after the end of the Second World War, immediately after the forced abdication of King Michael I on December 30, 1947 and the proclamation of the People's Republic, so that it would come completely under communist influence. Soviet-style reforms are unfolding at an ever-increasing rate. The law of education, the law of the general regime of cults, the collectivization of agriculture, accelerated industrialization, the adoption of a new republican constitution, the dissolution of historical parties, the creation of the new Soviet man, the persecution of the Church are the essential coordinates of this reform. Under these conditions, the Church devised a survival strategy, being in a position to accept even a series of official compromises in the hope of keeping alive the core of its Christic message [1]. During all this period, the patriarch Justinian (1948-1977) was at the head of the Romanian Orthodox Church, considered by some as the Providential Man, and by another part of the historians as "the red patriarch". The state of popular democracy is an instrument of the working class, which overthrew the exploiting classes and thus established the dictatorship of the proletariat. The aim of this revolution was the cela to establish a classless society, egalitarian suppression institutions have maintained social inequality: the monarchy, private property, generalization popular property, working as a supreme value of society, limiting the reorganization of the monastic life as so the goals of popular democracy to be achieved [2]. At the heart of this new revolution is the "new man", the one who brings with him "the change in the face of the world and who knows how to capitalize through hard work the opportunities generously offered by popular democracy"[3]. Not being possible a complete abolition of the Church as in Russia, the Romanian communist state adopted a different strategy, to undermine it, gradually, through laws and progressive restrictions, while maintaining the appearance of a certain freedom of conscience, the prerogative of popular democracies. The Church enjoyed a certain policy of subsidizing its clergy and church historical monuments, the freedom to exercise divine worship inside the sacred place, keeping institutions for training clergy under the authority of the Church, tolerating the existence of monasteries, the existence of a limited number of publications religious, minimal welfare activity complicated, freedom of conscience, however the Church involvement in supporting the activities of the State: the collectivization of agriculture, fight for peace, the general state property, etc. Instead, the Church accepted a certain collaboration with the State, not in the sense of the Caesaro-papism [4], but in the restructuring of society at all levels, by virtue of the Byzantine tradition that enshrines the principle of symphony between it and state, as Justinian wrote in the Social Apostolate: "collaboration corresponds entirely to the ancient traditions of Eastern Christianity organized on a national basis and for it to cooperate in the service of the public good with the state on whose territory it carries out its work of salvation of its own believers [5] ". The legitimation of the Church in the new political construct is represented by the recourse to the people, to its service, a fact that justifies the existence of the Church and at the same time constitutes a common action with the state power. 


\section{$3^{\text {rd }}$ International Conference On Research In HUMANITIES \& SOCIAL SCIENCES}

\section{Research methodology}

Carrying out this approach, synthetic and critical at the same time, this article aims to contribute to deciphering the way in which the Church cross the period of popular democracy. The reaction to the new challenges facing the Church in Romania allows us to evaluate more precisely the role of Patriarch Justinian in shaping a certain modus vivendi between the Church and the State. Its model of discourse and action represent a form of passive resistance of the Church as a whole. This article benefits from the opening of the archives of the State Security (CNSAS), and many of the published information notes could shed new light on the period under discussion and thanks to these documents, the historical truth can be established more precisely. The official discourse of the communist state was put in antithesis with the existing archive documents, and from this juxtaposition, we can discover the type of duplicitous discourse of the communist regime, and the types of answers offered by the Romanian Orthodox Church to these challenges.

\section{Argumentation. The paradox of the communism}

The Constitution of 1948, in art. 27 enshrines freedom of conscience and religion, obviously being applied in the communist style. Gradually, these freedoms of the Church became more and more restricted, revealing more and more the true plans of power. Justinian, knowing that he could not openly oppose the communist system, adopted the strategy of a fake enthusiasm for communist values and politics, thus trying to discreetly save what was essential to the Church. One of the informants stated: "The regime needs the Church, at the head of which the patriarch stands; $\mathrm{He}$ is aware that behind him are 12,000,000 believers, while the party has several thousand rogues... [6]."

One of the means of restricting the freedom of the Church was to limit the number of priests and implicitly the number of places in theological schools, so that some of the churches would close due to the lack of priests. Church income reduction, collectivisation of agriculture and the annual plans of development were initiated in order to gradually restrict the practice of faith. Some of the priests were accused of undermining the national economy or of "counter revolutionary" activity and were removed from the lists of subsidies. These funds necessary for the salaries of the clergy were an instrument of pressure for the communist state. The church was forced to give up the land owned by parishes and monasteries, thus depriving much of the goods that ensured a certain freedom of action, starting in 1949, continuing with 1950, in the context of propaganda for collectivization. Circular no. 334/18 March 1949 issued with the approval of the Ministry of Agriculture, allowed under certain conditions that priests and monasteries keep some lands for their own maintenance, between 3-5 hectares. On June 5, 1950, the patriarch conditioned the support of the Church for the campaign to raise the crops, to keep the clerical posts, stating that the Law of Cults must be respected, and on the other hand, that the removal of priests from budget could mean mobilizing villages against Romanian Socialist Party, knowing the case of the priest Bălteanu[7]. If in the case of the fight for peace, the patriarch had to mobilize the priests for this action, this time, he states that he can do nothing as long as the salaries of the priests are in danger to being suppressed. Keeping wages in the 


\section{$3^{\text {rd }}$ International Conference On Research In HUMANITIES \& SOCIAL SCIENCES}

national budget will be not just a form of supporting the needs of clergy families, it was an official form of recognizing their status in a communist society, it was an act of accepting their purpose in the new arrangement, in a context in which through official propaganda the clergy were accused of uselessness and parasitism [8].

\section{The reform of monasticism}

Obviously, in the popular society, the monasteries had no place, being considered a place of refuge for the political reaction, for the leaders of the former political parties that had been abolished, a space of " sick mysticism". In the face of this danger, Justinian thought of transforming the monasteries into real production units, to be accepted in the new common order, in which the production of concrete goods was a priority. So, monasteries had to open the animal farms, flower greenhouses, orchards, weaving workshops, museum collections, handicrafts, etc. All this brought significant amounts to the state budget, especially through the products that were exported. However, paradoxically, after 10 years of anti-monastic policy, there is an increase the number of monks in monasteries, as well as an increasing of the interest of monks in higher theological studies. If in 1948 there were 154 monasteries with 4,100 monks, in 1958 the number of these establishments was 191 and the number of monks was 6400. Finally, there was an increasing in both the economic activity of the monasteries, and growth of the cultural level of the living.

On October 6, 1959, the Minister of Interior Alexandru Drăghici made a series of proposals with the clear aim of destroying monasticism, considered a true elite army of the Church [9]. These measures include: reducing the volume of orders sent to monasteries, liquidating the contracts of state units working in collaboration with monasteries, developing production units with the same specificity to boycott the products of monasteries [10]. All these will be only the preamble of the frontal blow given to monasticism by decree $410 / 1959$ by which almost all the monasteries were abolished, for this being necessary the mobilization of the supreme popular forum, the Great National Assembly.

\section{Theological Education}

On August 3, 1948, the Law on the General Regime of Cults, Decree 177/1948, was voted. This decree eliminates theology from the University and transformed the respective Faculties into Theological Institutes. At the same time, some of the theological seminaries and faculties were being abolished. The 6 Theological Seminaries were placed under the jurisdiction of the Church, but with the control of the Ministry of Cults, one for each metropolis (Neamt, Buzău, Bucharest, Caransebes, Cluj and Craiova) and 2 higher theological institutes, respectively, in Bucharest and Sibiu. However, although the ministers of cults stated that only under the regime of popular democracy did the Church regain its full function of serving the interests of the people, the purpose of the measures was to gradually extinguish the Church's message and eliminate it from people's lives. Paradoxically, these measures, although restrictive and abusive, also generated some beneficial effects. Thus, with great efforts, Patriarch Justinian managed to maintain a high standard of quality regarding the analytical program unburdened 


\section{$3^{\text {rd }}$ International Conference On Research In HUMANITIES \& SOCIAL SCIENCES}

by political issues, he formed a body of elite professors who kept alive the flame of Orthodox theology through studies, translations, publications, etc. The Law of the general regime of Cults also imposes some restrictions on the connections with those from abroad, the situation of domestic donations, the conditional maintenance of salary subsidies, the prohibition of any form of proselytising, loyalty to the state and communist order, etc. The text of the oath taken by the dignitaries of the Church at their investiture in office is edifying [11], by forcing the newly invested at loyalty to an oppressive and atheist state,

\section{Failure of Missionary Guidance on the " Benefits of Communism"}

The popular democratic regime had come up with a series of reforms that upset the whole society and uprooted it from its traditional core, therefore the reaction or distrust that most of the Romanian people showed was natural. The priests were trained to carry out the work of convincing their parishes to the success of collectivization, the struggle for peace, the antimonarchical attitude, etc. These courses were intended to be an instrument for implementing communist-type policies, but in reality, Patriarch Justinian made them an instrument for strengthening pastoral faith and practice. Adrian Gabor and Nicolas Adrian Petcu showed that through a double speech, without betraying the evangelical message, and without irritating the communist authorities, the patriarch managed to make himself understood both by the communist power and the simple priests [12].

A report by the General Directorate of People's Security of 1949 states in conclusive results of these courses missionary guidance though systematic boycotts both by teachers and audience who prefer to debate pastoral and church administration issues, than the ideological themes imposed by the Party. On the other hand, the Ministry of Religious Affairs think the teachers required to make political education were supporters of democratic parties or members of the anti-communist movement. This was the case of the rector Nicolae Nicolaescu, joining several parties, prof. Emilian Vasilescu was considered "reactionary", prof. Teodor Popescu was considered an exponent affiliated to "Gândirea", prof. Ioan Gh. Coman and Mircea Vintilescu were sympathizers of the liberals, Prof. Gh. I. Moisescu were considered legionaries and Nicolae Chițescu was considered a liberal sympathizer, close to Gh. I Brătianu, leader of the Liberal Party, and prof. Dumitru Stăniloae was considered a mystic man. The rapporteur wrote: "Although the topics of the conferences are democratic, however, through the discussions at their end, the democratic level of these conferences is lost."[13]. Prof. Mircea Chialda, as well as all theology professors, either refused to deal with political subjects, or treated them superficially, or mocked them, so that the political stakes of these courses were compromised. [14]. With such teachers, it was clear to the communist dignitaries that they would not be able to make a new, "democratic " type of education for priests. Bishop Nicolae Popovici at the opening of the fifth series of courses missionary guidance in 1950 has spoken openly that "the Romanian People's Republic began the war against religion, and priests must prepare to face the enemies of God at the expense of their lives [15]". 


\section{$3^{\text {rd }}$ International Conference On Research In HUMANITIES \& SOCIAL SCIENCES}

\section{Catechesis of young people}

Although the constitution provided for the freedom to exercise worship, conscience and religious freedom [16], however, in practice, the atheist regime was incompatible with spreading the message of faith [17]. Although religious freedom was legally established, in reality thousands of priests and monks were arrested for various reasons and then sentenced to many years in prison. Arrested in successive waves, even in 1949, those who survived until 1964 benefited of cancel the sentences, as a result of international pressure on the regime. Therefore, the regime did everything necessary to prevent the catechesis of young people. The Education Law of 1948 eliminated the teaching of religion in state schools, which was replaced by communist propaganda. Bishop Kesarie of Constantza and other bishops proposed that Sunday afternoon to do the catechismus in churches from 31 october 1948. The State Security agents were present in the churches and they discouraged those who wanted to participate [18]. Patriarch asked to the Holy Synod to approved a decision to make youth catechesis for an hour, voluntarily on Saturday afternoon or Sunday. The Synod approved the proposal in October 1950, but the Ministry of Culture's the opposite to the initiatives which seriously should compromise the atheistic education of youth.

\section{Conclusions}

The popular-democracy in Romania, 1948-1965 was the first and most serious of steps for installing the communism in Romania. The Romanian Orthodox Church had to use a double discourse with the state leadership and with the people. The religious freedom of public manifestation of faith was affirmed officially, but the state did everything to compromise the Christian message. Under such conditions, Patriarch Justinian build a strategy for the survival of the Church and the key of this strategy was his multivalent discourse, meant not to harm the sensibilities of the communists, and not to betray the mission and evangelical mission. The commitment regarding the involvement of the Church in supporting political and social projects such as: collectivization of agriculture, generalization of state property, rejection of the monarchy, struggle for peace and nuclear disarmament, restructuring of monasticism are just some actions that the Church has done under the regime of popular democracy to save the incandescent core of its mission, through a passive resistance to communist aggression. The testimony of thousands of heroes of the faith during this period, priests or simple believers, who refused any compromise, is another form of resistance, active, face to the same atheist regime. The Byzantine symphony has fail, despite the enthusiastic appearances of the state and the Church, being rather a discordant symphony. 


\section{icrhs}

\section{$3^{\text {rd }}$ International Conference On Research In HUMANITIES \& SOCIAL SCIENCES}

11-13 September 2020

Brussels, Belgium

\section{References}

[1] Ovidiu Bozgan, "State, Orthodoxy and Catholicism, in Communist Romania," in History Files, year VI, (2001), no.5, p.21.

[2] Stanciu Stoian, “Religious Cults in the Romanian People's Republic”, Bucharest, 1949, pp.11-51.

[3] George Enache, "Orthodoxy and Political Power in Contemporary Romania", Nemira Publishing House, Bucharest, 2005, p. 25.

[4] Olivier Gillet, "Religion and Nationalism. The ideology of the Romanian Orthodox Church under the communist regime ", trans. by Mariana Petrișor, Bucharest, 2000, p. 17.

[5] Justinian, "Social Apostolate. Parables and Exhortations for the Clergy, "IBMBOR Publishing House, vol. X, Bucharest, 1976, p. 49.

[6] Information note dated 19 March 1950, ACNSAS, File 67. Documentary fund, p. 211.

[7] George Enache, " Orthodoxy and Political Power in Romania ... ”, pp. 98-102.

[8] Jean Meyendorff, The Orthodox Church Yesterday and Today, "trans. Cătălin Lazurcă, Bucharest, 1996, p. 110 .

[9] Cristina Păiușan , Radu Ciuceanu, "The Romanian Orthodox Church under the communist regime, " Publishing House of the National Institute for the Study of Totalitarianism, Bucharest, 2001, p.320-333.

[10] Constantin Aioanei, Frusinica Moraru, "The Romanian Orthodox Church in the fight against the red devil," in MItropolia Banatului, 2001, no.1-3, pp.88-99.

[11] Art 21 of Decree 177/1948: As a servant of God, as a man and as a citizen, I swear to be faithful to the People and to defend the Romanian People's Republic, against enemies from outside and inside; I swear that I will respect you too enforces by my subordinates the laws of the Romanian People's Republic; I swear that I will not allow my subordinates to undertake and take part and I will not undertake and will not take part in any action that could harm the public order and integrity of the Romanian People's Republic. God help me! "

[12] Fr. Gabor Adrian, Nicolae Adrian Petcu, "The Romanian Orthodox Church and the communist power during the patriarch Justinian”, in the Yearbook of the Faculty of Orthodox Theology, Bucharest, 2002, pp. 113-123.

[13] Cristina Păiușan, Radu Ciuceanu , “Romanian Orthodox Church...” p. 188.

[14] Prof. Mircea Chialda, for example, stated, according to an informative note that: "in the conferences I hold at the priests' guidance courses, although I had political topics, I did not take any more steps than I should have. I did not become a servant of the Russians to always say parrotingly that the USSR is the most advanced in the world, that Soviet science is the most... or that the great, brilliant, glorious Stalin,.... I refused these superlative because firstly, I am a Romanian, and secondly, I am a teacher... ”. Cristina Păiușan, Radu Ciuceanu, Romanian Orthodox Church....", p. 192.

[15] George Enache, Orthodoxy and Political Power in Contemporary Romania ... ”p. 114. 


\section{icrhs}

\section{$3^{\text {rd }}$ International Conference On Research In HUMANITIES \& SOCIAL SCIENCES}

[16] Art. 6. "Freedom of conscience and religious freedom are guaranteed by the State. Art. 7. Religious cults are free to organize and can function freely if their ritual and practice are not contrary to the Constitution, public security or good morals. No denomination, congregation or religious community may open or maintain general education institutions, but only special schools for the training of the cult staff under the control of the state".

[17] Art. 27 of Constitution provided that: " Religious cults are free to organize and may function freely if their practices and ritual are not contrary to the Constitution, security or public order and morals." ART. 7 of Decree $178 / 1949$ provided that " Religious cults shall be organized according to their own norms, according to their teachings, canons, and traditions, and may be organized according to the same norms, establishments, associations, orders and congregations . "

[18] ACNSAS, Documentary Fund, pp. 40, pp. 52. 